\title{
Partidos, Competição Política e Fraude Eleitoral: A Tônica das Eleições na Primeira República*
}

\author{
Paolo Ricci ${ }^{1}$ \\ Jaqueline Porto Zulini \\ ${ }^{1}$ Professor de Ciência Política da Universidade de São Paulo (USP). São Paulo, SP, Brasil. \\ E-mail: paolo.ricci@terra.com.br. \\ ${ }^{2}$ Doutoranda em Ciência Política pela Universidade de São Paulo (USP). E-mail: \\ jaquepz@gmail.com.
}

\section{INTRODUÇÃO}

Como em nosso pais a Republica é uma mentira, as eleições uma utopia, a justiça uma quimera e a

Constituição uma ponta de charuto que se fuma atè queimar os labíos, depois de amanha um silencio misterioso envolverá todas as secções eleitorais porque o cidadão de brio e independente no nosso meio, evitando na sua laboriosa atividade papel de comediante, não se dá ao trabalho de procurar na gaveta ou no bau seu papelucho ridículo a que dão o nome do título e se dirigir à secção para votar num candidato a quem os caudilhos já elegeram, reconheceram e vão empossar. E desse sepulcro

das eleições veremos sair eleitos verdadeiros representantes da fraude e da mentira [...] (A Lucta, 28 de janeiro de 1915).

\begin{abstract}
A acusação do jornal cearense $A$ Lucta era precisa e direta: os pleitos no Brasil do século XIX não suplantavam uma mísera peça teatral, dado o grand finale sempre se desenhar a priori. Passados cem anos, este retrato caricatural permanece inalterado: a Primeira República
\end{abstract}

\footnotetext{
* Versão preliminar deste artigo foi apresentada no 8ํㅡㄹ Encontro da Associação Brasileira de Ciência Política (ABCP), realizado em Gramado, de 1 a 4 de agosto de 2012. Agradecemos os comentários de Lorena G. Barberia, Fernando Limongi, Ângela de Castro Gomes e Jairo Nicolau às versões parciais que antecederam a formulação final do texto.
}

DADOS - Revista de Ciências Sociais, Rio de Janeiro, vol. 57, no2 2, 2014, pp. 443 a 479. 
(1889-1930) entrou para os anais da história brasileira como arauto da farsa eleitoral. Generalizada, a fraude tornaria a manutenção de escrutínios regulares para todos os níveis de governo durante o regime, na prática, mero formalismo (Leal, 1997; Porto, 2002; Carvalho, 2003). Fraudados e fictícios, os procedimentos eleitorais permitiriam a sistemática exclusão de oposições no cenário decisório do período, asseverando o congelamento da competição política no país (Lessa, 1988; Lima Júnior, 1999; Motta, 2008).

Na prática, a associação imediata entre escrutínios e fraude tem aniquilado até hoje qualquer esforço de aprofundamento na crítica das eleições em época republicana ${ }^{1}$. No caso específico das propaladas táticas de corrupção dos pleitos, os registros disponíveis simplesmente perfazem testemunhos de época e crônicas jornalísticas. No máximo, descrevem-se os métodos mais comuns de se forjar vitórias e barrar o avanço das oposições, mas sem nenhuma ambição explicativa. Permanece desconhecida a grandeza de um elemento difícil de ser medido, mas factível de investigação.

Procurando entender a causa primeira das supostamente correntes alegações de fraude e suas inúmeras manifestações, recorremos à leitura das contestações ou petições formais aos escrutínios realizados para a Câmara Federal ${ }^{2}$. Trata-se de documentos oficiais apresentados aos parlamentos pelos candidatos derrotados que protestavam a lisura dos pleitos e seus saldos posteriores. A metodologia do estudo que estamos apresentando é nova no Brasil, mas já foi explorada em outros estudos de casos. Acreditamos que essas acusações formais de irregularidade na seleção do corpo legislativo nos permitem enveredar, por via inédita, nas práticas fraudulentas ditas habituais ao jogo eleitoral da Primeira República.

O estudo das reclamações oferecidas pelos candidatos contestantes buscará superar a antítese mais trivial entre os approaches quantitativo e qualitativo. Inicialmente, nos serviremos de um tratamento numérico visando um melhor entendimento da dinâmica política dos anos republicanos através da crítica de dados mais robustos, que relativizam as impressões disseminadas ainda hoje pelos livros de história. Veremos que a competição político-partidária, de influência tida por certa e usada como controle pela maioria dos exames dirigidos a outras experiências mundo afora, emerge enquanto elemento determinante das alegações de fraudes eleitorais observadas também no Brasil republi- 
cano. Na sequência, investigaremos o conteúdo dos protestos. Decodificando as reclamações mais comuns, traduzimos os reagentes que culminam no eligir da competição partidária. Em comum, os depoimentos analisados destacam a ausência do domínio oligárquico sobre a "máquina eleitoral" como o status propulsor e chave elementar de leitura para a manifestação da fraude durante a Primeira República.

\section{AS ELEIÇÕES NA PRIMEIRA REPÚBLICA: A CENTRALIDADE DO MUNICÍPIO}

Após a Assembleia Constituinte de 1891, a primeira eleição para a escolha dos representantes federais da Câmara e do Senado ocorreu em 1894, repetindo-se a cada três anos até a Revolução de 1930³. Especialmente com respeito à Câmara Baixa, nosso recorte de interesse, o número de deputados era definido por lei, conforme a previsão constitucional, em proporção nunca superior "de um por setenta mil habitantes (1:70.000)", nem tampouco devendo esse número "ser inferior a quatro por Estado" (Constituição de 1891, art. 28), deixando, portanto, ao legislador ordinário, o poder de detalhar a matéria. De fato, o delineamento das circunscrições eleitorais seria redesenhado ao longo do regime, já que o distrito não era equivalente ao estado quando se tratavam das unidades federativas mais populosas. Até os primórdios do século $\mathrm{XX}$, os estados que elegiam no máximo cinco representantes para a Casa constituíam um único distrito, enquanto os demais se mantinham divididos em circunscrições de três deputados, respeitando o critério da proporcionalidade (cf. a Lei no 35, de 26 de janeiro de 1892). Com a promulgação da Lei Rosa e Silva, como ficou conhecida a primeira reforma eleitoral de monta aprovada na República, a 15 de novembro de 1904, determinou-se a redistribuição dos distritos por unidade federada. Os estados que elegiam até sete deputados passaram então a constituir um distrito único - nas demais situações, os distritos encerrariam cinco deputados. A Tabela 1 sumariza as variações nos distritos eleitorais durante a Primeira República.

Como se vê, a redefinição das fronteiras eleitorais não alterou a composição da Câmara Baixa, fixando-se em 212 o número de deputados. O estado que elegia mais representantes para a Casa era Minas Gerais, com direito a 37 vagas. Seguiam-no São Paulo e Bahia, com 22 deputados, Pernambuco e Rio de Janeiro com 17 cadeiras, Rio Grande do Sul com 16, e os demais estados com bancadas variando entre 4 e 10 membros. Daí parte da propalada preponderância política de São Paulo e 
Paolo Ricci e Jaqueline Porto Zulini

Tabela 1

Magnitude dos Estados e suas Respectivas Subdivisões Distritais durante a

Primeira República

\begin{tabular}{|c|c|c|c|}
\hline \multirow[t]{2}{*}{ Estados } & \multirow{2}{*}{$\begin{array}{c}\text { Magnitude dos Estados } \\
\left(\mathrm{n}^{\mathrm{o}} \text { de deputados }\right)\end{array}$} & \multicolumn{2}{|c|}{ Número de Distritos Fixados por Lei } \\
\hline & & $\begin{array}{c}\text { Norma Eleitoral } \\
\text { de } 1892\end{array}$ & $\begin{array}{c}\text { Norma Eleitoral } \\
\text { de } 1904\end{array}$ \\
\hline Minas Gerais & 37 & 12 & 7 \\
\hline São Paulo & 22 & 7 & 4 \\
\hline Bahia & 22 & 7 & 4 \\
\hline Rio de Janeiro & 17 & 5 & 3 \\
\hline Pernambuco & 17 & 5 & 3 \\
\hline Rio Grande do Sul & 16 & 5 & 3 \\
\hline Distrito Federal & 10 & 3 & 2 \\
\hline Ceará & 10 & 3 & 2 \\
\hline Pará & 7 & 2 & 1 \\
\hline Maranhão & 7 & 2 & 1 \\
\hline Alagoas & 6 & 2 & 1 \\
\hline Paraíba & 5 & 1 & 1 \\
\hline Piauí & 4 & 1 & 1 \\
\hline Sergipe & 4 & 1 & 1 \\
\hline Rio Grande do Norte & 4 & 1 & 1 \\
\hline Paraná & 4 & 1 & 1 \\
\hline Santa Catarina & 4 & 1 & 1 \\
\hline Goiás & 4 & 1 & 1 \\
\hline Amazonas & 4 & 1 & 1 \\
\hline Espírito Santo & 4 & 1 & 1 \\
\hline Mato Grosso & 4 & 1 & 1 \\
\hline Total & 212 & 63 & 41 \\
\hline
\end{tabular}

Fonte: Leis $\mathrm{n}^{\mathrm{o}}$ 35, de 26 de janeiro de 1892 e n⿳ํㅡㄴ.269, de 15 de novembro de 1904 .

Minas no sistema político em tela, uma vez que detinham, sozinhos, $28 \%$ das cadeiras na Câmara. Quando considerados os outros estados mais importantes, em termos de população e força econômica, como Bahia, Rio Grande do Sul e Pernambuco, o percentual sobe para $54 \%$.

A unidade territorial imediatamente inferior ao distrito era o município - e eis o ponto que nos interessa frisar: o âmbito local constituía não somente o foro ordinário dos escrutínios, mas o espaço privilegiado da competição política na era republicana. Isto porque a análise das prin- 
cipais normativas eleitorais promulgadas no período revela a centralidade do município nas fases decisivas dos pleitos ${ }^{4}$. Explicamos a partir de uma breve introdução ao modus operandi dos escrutínios à época, diversa da lógica vigente nos dias atuais. No Brasil de princípios do século XX, o processo eleitoral contava com pelo menos quatro etapas burocráticas necessárias à viabilização dos pleitos, a saber: i) a fase pré-eleitoral (provisão de alistamento, divisão do município em seções, definição dos locais de votação e eleição dos membros das mesas eleitorais); ii) o momento eleitoral (a votação em si); iii) a fase de apuração dos resultados (contagem primária dos votos nas seções, cujas atas se fariam depois totalizadas nas juntas apuradoras distritais, havendo espaço para registro de eventuais contestações nos dois momentos); e iv) o reconhecimento dos poderes dos eleitos (na ausência da Justiça Eleitoral, criada somente em 1932, realizado pelos próprios diplomados no Parlamento). Não é exagero dizer que os três primeiros passos deste circuito encontravam-se condicionados à esfera municipal.

Com efeito, a primeira etapa, de caráter preparatório, sempre esteve atrelada à influência das forças políticas locais. Seu desafio inicial - a provisão do alistamento e qualificação dos aptos a votar - se mostrava cuidadosamente conduzido pelos dirigentes municipais. A Lei $\mathrm{n}$ 35/1892 determinava que os membros efetivos do governo local (Câmara, Intendência ou Conselho) e seus imediatos em votos, reunidos em data e lugar noticiados pela imprensa, procedessem à divisão do município em seções e, sucessivamente, à eleição de cinco membros efetivos e dois suplentes, assim elencados para formar cada uma das comissões seccionais de alistamento, cujos quatro componentes deveriam ser escolhidos dentre os eleitores da municipalidade ${ }^{5}$. Somente depois desse levantamento prévio, uma comissão especial, composta pelos presidentes das comissões seccionais de alistamento e chefiada pelo prefeito da cidade ${ }^{6}$, faria a consolidação dos pedidos de qualificação, a revisão dos alistamentos seccionais e a decisão sobre eventuais reclamações fundadas em alegações de inclusões indevidas e/ou não inclusões (cf. a Lei no 35/1892, cap. III). Os títulos eleitorais então concedidos podiam finalmente ser entregues aos seus respectivos requerentes logo após a assinatura do prefeito (idem, cap. V). A partir da Lei Rosa e Silva, a qualificação dos aptos a votar deixa de ser realizada por várias subcomissões seccionais ${ }^{7}$. Pela primeira vez, a magistratura entra em cena neste processo preliminar, com a exigência da presença do juiz de direito da comarca - "ou quem suas vezes fizesse" - na presidência da reunião entre dirigentes locais em prol da eleição de uma 
única comissão especial de alistamento ${ }^{8}$. Dependendo do caso, a autoridade judiciária competente para tanto passa a ser o juiz estadual "de categoria mais elevada" ou, mesmo, o "ajudante do procurador da República" - embora a preferência fosse priorizar o serventuário de justiça local $^{9}$. Também a partir da reforma de 1904, os requerimentos para o alistamento e as provas exigidas neste fim, dantes facilitadas, passam a exigir a rubrica das autoridades judiciárias ${ }^{10}$. O próprio pedido, por escrito, deve agora vir datado e assinado, com firma reconhecida pelo tabelião de nota "do lugar"11. Por motivo semelhante, outros burocratas acabam por figurar na nova normativa eleitoral. Isto porque os maiores contribuintes do município ingressam na rodada de definição e organização da comissão de alistamento (Lei no 1.269/1904, art. 8o). Coletores e agentes fiscais têm, assim, particularidades de seu trabalho discriminadas no texto da norma eleitoral da vez, pois se viam ali responsabilizados pela consulta aos livros de lançamentos dos impostos e pelo posterior preparo da listagem dos maiores contribuintes do município. De tudo exposto, emerge como única alteração sensível promovida pela reforma de 1916 - em se tratando dos procedimentos exclusivos das comissões de alistamento - a expropriação da prerrogativa da definição dos locais de votação ${ }^{12}$, que se transmuta em nova atividade centralizada pelos juízes de direito de cada comarca (Lei no 3.208/1916, art. $\left.8^{\circ}\right)$.

Na escalada preparatória dos escrutínios, o último degrau, representado na eleição dos membros das mesas coordenadoras do dia da votação, configurava justamente o elo à fase subsequente - isto é, o momento do pleito. Como nas subetapas anteriores, a precedência do poder local na composição destes corpos, que deveriam funcionar em cada seção da municipalidade, era inconteste. A constituição das mesas se dava na mesma lógica perseguida nas nomeações das comissões seccionais de alistamento - lembrando: via escolha inicial, ratificada entre membros efetivos do governo local e seus imediatos em votos, de uma comissão de cinco participantes efetivos e dois suplentes, logo habilitados a constituir cada uma das mesas seccionais (Lei no 35/1892, art.

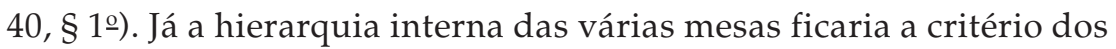
votos de seus próprios pares no ato de instalação das mesmas, separadamente, quando deveriam eleger o presidente e o secretário da seção eleitoral para a distribuição das respectivas incumbências prosseguir (idem, art. 43). Assim como no caso do alistamento, a reforma de 1904 inclui a magistratura também no processo de escolha das mesas eleitorais. Dizia a Lei Rosa e Silva que, dali em diante, os referidos corpos se- 
riam organizados por uma junta composta do $1^{\circ}$ suplente do substituto do juiz seccional, como presidente, sem voto, do ajudante do procurador da República, igualmente sem voto, dos membros efetivos da comissão de alistamento e dos seus respectivos suplentes ${ }^{13}$. Todavia, abria-se espaço inédito para as indicações de mesários ${ }^{14}$ oferecidas pelos eleitores, capazes de fazê-lo desde que encaminhassem ofício reunindo a assinatura de 30 homens ou mais, qualificados na mesma seção, acompanhadas de firma reconhecida por tabelião público ${ }^{15}$. $\mathrm{Na}$ verdade, essa "brecha" para a incorporação dos eleitores nas mesas de suas respectivas seções de votação até seria mantida nas prescrições eleitorais aprovadas em 1916, observando-se, porém, a partir de então, a tutela dos serventuários de justiça nas escolhas dos escrutinadores, uma vez que os representantes judiciais agora têm voto. Os membros das comissões de alistamento saem de cena: na sede das comarcas, são o juiz de Direito, o 1o suplente do substituto do juiz federal e o presidente do Conselho, Câmara ou Intendência Municipal que definem os membros das mesas eleitorais ${ }^{16}$. No limite, a presença física dos representantes judiciais se tornou o critério para a divisão seccional dos municípios a partir da reforma eleitoral de $1916^{17}$.

Fato é que tamanho preciosismo na constituição das mesas eleitorais não se mostrava nada gratuito. Dominá-las significava conduzir o desenrolar do pleito, eventualmente crítico até mesmo para os candidatos governistas, considerando que o controle sobre o alistamento não era completo. Afinal, os mesários geriam a votação: regravam a chamada dos eleitores, conferiam a lista dos qualificados, examinavam os títulos apresentados por cada cidadão e afiançavam a entrada dos fiscais apresentados pelos candidatos no recinto (Lei no 35/1892, art. 43). Mais relevante ainda: tratava-se dos homens que engatavam a apuração preliminar dos votos, na seção, tão logo encerrado o pleito. No caso, o presidente (ou quem o substituísse), auxiliado pelos escrutinadores, abria a urna e apurava os votos dados aos candidatos - cujo resultado era transcrito na ata da secção. Até a reforma de 1916, uma cópia da ata, após lavrada, era enviada ao prefeito da cidade-sede de cada circunscrição eleitoral, onde se instalava a Junta Apuradora Distrital, encarregada de executar a soma dos votos constantes das cópias das atas seccionais recebidas (Lei $n-35 / 1892$, art. 44, § 60). Aqui, o presidente do governo municipal, os cinco candidatos mais votados e os cinco imediatamente menos votados passavam a uma nova apuração do pleito. O resultado das eleições era transcrito na ata geral da apuração, que continha não apenas a ordem de votação dos candidatos, como 
também as reclamações e os protestos apresentados durante os trabalhos da referida Junta ou perante as mesas de cada seção. No pós-reforma, as Juntas Apuradoras distritais são abolidas, exigindo-se a instalação de um só corpo na capital de cada estado para se lavrar a ata de apuração geral a partir do exame de todas as atas seccionais recebidas ${ }^{18}$ - mantendo-se, assim, como responsabilidade elementar do órgão a condução do processo de contagem dos sufrágios e divulgação do resultado do pleito, sem recair em renovo da contabilização dos totais indicados nas atas das seções. Independentemente dessa mudança, permaneceu incólume o caráter documental da ata geral, compreendido à luz do dispositivo legal que determinava a remessa da mesma aos candidatos eleitos "para lhe servir de diploma". Ambicionado passaporte dos candidatos ao Legislativo Federal, a cópia dessa ata, devidamente rubricada pelos membros da Junta Apuradora, era também remetida à Câmara dos Deputados, onde se daria a última fase do processo de validação dos escrutínios.

No chamado "terceiro escrutínio", como ficou conhecida a prática constitucional da época ${ }^{19}$, os próprios parlamentares tinham de pronunciar um juízo definitivo sobre os diplomas expedidos pelas Juntas Apuradoras, resolvendo ainda eventuais contestações e protestos e, em geral, qualquer reclamação apresentada durante a apuração dos votos - tudo após as apurações já finalizadas, primeiro nas seções e depois no seio das Juntas Apuradoras ${ }^{20}$. O processo de reconhecimento final dos diplomas se repartia em duas fases, respaldado, no caso em tela, nas prescrições do regimento interno da Câmara ${ }^{21}$. Na primeira delas, os diplomas apresentados pelos candidatos passavam pelo crivo de uma comissão nomeada pelo presidente provisório da Câmara, composta de cinco membros - justamente por este motivo denominada "Comissão dos Cinco". Partindo do rol de diplomas apresentados pelos próprios aspirantes a deputados, tal corpo organizava uma primeira listagem dos certificados que aparentemente revestiam as condições legais, considerados legítimos. Para ter validade, a lista precisava ser aprovada em plenário, embora o mesmo ainda não estivesse legalmente constituído, por se tratarem de sessões preparatórias. A saída regimental se mostrava deveras maquiavélica neste ponto, ao caracterizar como aptos para as votações em plenário somente os candidatos constantes da lista apresentada pela Comissão dos Cinco. Instituía-se por esta via o autorreconhecimento, uma vez habilitados os supostos deputados, previamente reconhecidos pela Comissão dos Cinco, a decidirem sobre a validade não apenas dos documentos exibidos por seus 
pares, como também sobre seus próprios diplomas. Os mesmos parlamentares adquiriam ainda o direito de participar do ciclo sucessivo, assim como de debater e deliberar no plenário durante as sessões preparatórias ${ }^{22}$. Este segundo momento principiava quando os parlamentares legalmente reconhecidos pela Comissão dos Cinco eram sorteados para compor as Comissões de Inquérito, cujas funções eram as de relacionar a totalidade dos diplomas por estado, analisar as contestações e as reclamações e, em última instância, formular os pareceres em torno dos diplomas expedidos pelas Juntas Apuradoras, além de, eventualmente, dissentir da escolha feita pela Comissão dos $\mathrm{Cinco}^{23}$. Deliberados cada um dos diplomas, finalmente se concluía a certificação dos resultados eleitorais na Primeira República.

O fluxograma a seguir resume a cadeia de etapas mínimas necessárias à eleição dos deputados federais no período, desde os procedimentos de alistamento até o reconhecimento dos poderes na Câmara. Membros da burocracia ativados em cada fase também são listados.

De acordo com a literatura, as tentativas de enviesar o método eleitoral se dividiriam entre as diferentes subetapas do processo de seleção dos representantes, incidindo desde o alistamento e qualificação dos eleitores (I) até os níveis subsequentes, quais fossem: o ato do voto em si (II), a apuração dos resultados em nível de seção e, sucessivamente, nas Juntas Apuradoras (III) e no reconhecimento dos poderes (IV) (Carvalho, 2003). Em outras palavras, lisura eleitoral definitivamente não era a palavra de ordem. Antes, prevalecia o deboche do sistema, vistas as saídas grosseiras então em moda. Para alguns, a definição dos aptos a votar representava excelente oportunidade de se alterar, $a$ priori, a performance dos candidatos - uma vez habilitada, nesta fase, a opção de se enveredar pela garantia estratégica da concessão do título eleitoral aos currais de interesse, com negativa para o eleitorado adversário (Faoro, 2001; Porto, 2004) ${ }^{24}$. Num período em que edifícios privados ainda sediavam os escrutínios eventualmente ${ }^{25}$, o momento de definição dos locais de votação reluzia em novo ensejo conveniente às tentativas de condicionamento dos resultados dos escrutínios. A transferência do privilégio de auditar tais designações para os juízes competentes a partir de 1916 não anulava, per se, a possibilidade de alguns candidatos abrirem as portas das próprias casas para os pleitos disputados por eles mesmos, a despeito do evidente constrangimento imputado ao comparecimento dos opositores naquelas seções, praticamente particulares, em vista da melhor recepção aos votos "amigos". 
Paolo Ricci e Jaqueline Porto Zulini

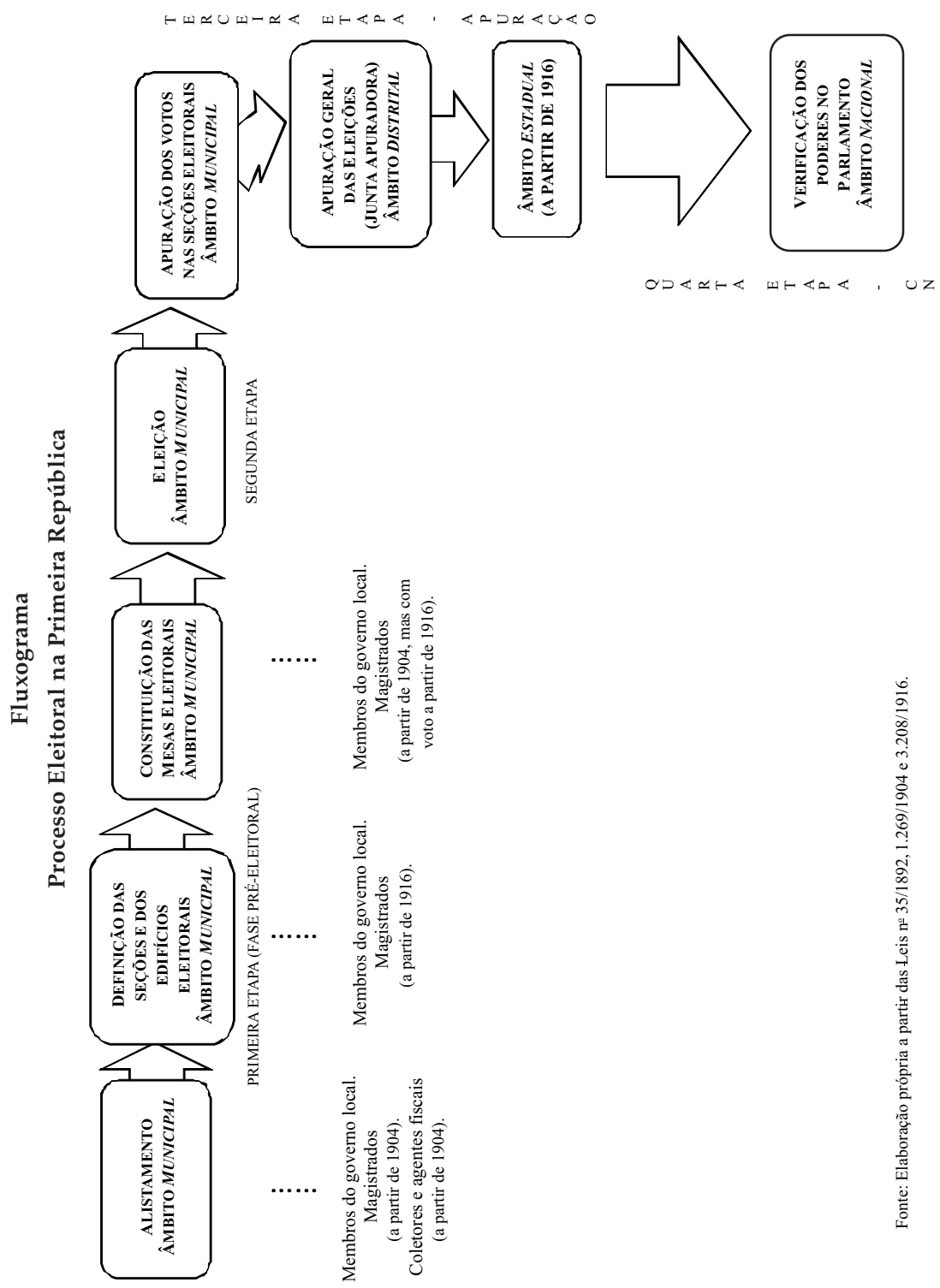

452 DADOS - Revista de Ciências Sociais, Rio de Janeiro, vol. 57, ํㅡ 2, 2014 
Outros estudiosos enfatizavam a fase da votação como objeto central das ações fraudulentas (Faoro, 2001; Leal, 1997; Kinzo, 1980; Telarolli, 1982). Para além do recurso à violência e à intimidação dos eleitores, que exigia, sobretudo, demonstração de força em lugar de raciocínio e técnica, arriscavam-se saídas mais audaciosas, a exemplo da utilização de "fósforos", como eram chamados os falsos eleitores hábeis em se passar pelos aptos a votar, porém ausentes ao escrutínio. Atrevimentos do gênero renderiam registros até de mortos nas listas eleitorais, quando não de menores ou estrangeiros. Isto sem contar o suposto registro de comparecimento às urnas de número de eleitores superior ao existente, segundo as próprias fontes oficiais, e os pleitos a bico de penaaqueles nos quais a própria mesa eleitoral adulterava as atas da votação em nível de seção ${ }^{26}$. Por fim, a fase da verificação dos poderes. Aqui, a literatura tem pintado um quadro da situação em que a degola - isto é, o não reconhecimento do diploma expedido no âmbito local - se manifestava como fato costumeiro (Carone, 1972; Leal, 1997; Carvalho, 2003). Na prática, os candidatos oposicionistas, mesmo que formalmente diplomados pelos órgãos competentes em âmbito subnacional, eram degolados pelo processo de verificação dos diplomas levado a cabo na esfera federal, durante as sessões preparatórias antecedentes à abertura do Congresso.

Neste artigo, retemos nossa atenção sobre as primeiras três etapas do processo eleitoral. A última delas, a da certificação dos escrutínios no Parlamento, será desconsiderada por duas razões. Primeiro, porque não remete à dinâmica dos escrutínios em si, mas às decisões finais tomadas na arena parlamentar, enquanto nosso propósito aqui é restringir o foco de análise às propaladas "imperfeições" do processo eleitoral republicano - e não tratar da verificação dos resultados no Congresso Nacional. O segundo motivo se funda nos achados de estudos recentes que, contrariando a visão comum na literatura, mostraram como o "terceiro escrutínio" não representa um momento de alteração substantivo dos resultados eleitorais (Ricci e Zulini, 2012 e 2013).

\section{A Fraude Eleitoral: Questões Metodológicas}

É coro uníssono na literatura o desafio que se coloca a toda e qualquer pesquisa que pretenda encontrar evidências da distorção dos resultados das urnas. Eisenstadt admite que "é mais fácil citar incidentes de fraude do que agregá-los em qualquer soma significativa dos efeitos deste fenômeno indescritível" (2002; tradução livre). Afinal, como 
bem lembra Lehoucq, "Ninguém que enche a urna quer deixar um rastro de provas incriminatórias" (2003:233; tradução livre) ${ }^{27}$.

Via de regra, os estudos dedicados à temática endossam o emprego das contestações eleitorais como proxy para a medição da fraude. As contestações eram queixas formais contra os resultados apurados: protestos interpostos aos órgãos legislativos responsáveis pela verificação dos poderes tanto por candidatos derrotados quanto por eleitores frustrados com a dinâmica do pleito. Documentadas, as reclamações às vezes solicitavam a anulação total dos escrutínios e, com mais frequência, o recálculo dos votos, com a exclusão das somas supostamente manipuladas - alternativa que redundava no pedido de reconhecimento dos perdedores. Desta forma, Lehoucq (2003) estimou o peso da deturpação dos resultados das urnas sobre o corpo legislativo federal empossado na Costa Rica. Saída correlata foi escolhida por Green (2007) no julgamento da experiência norte-americana, por Ziblatt (2009) e Anderson (2000) no tratamento do caso alemão, por Kam (2007) no estudo da Inglaterra, por Charnay (1964) no levantamento da fraude na França ou por Andreucci (1995) na abordagem da Itália liberal, para citar alguns ${ }^{28}$. Para todos eles, a apresentação de uma contestação formal era tida como proxy da existência da fraude.

Decerto, a solução não é perfeita. Normalmente, "as fontes mais abundantes para o estudo da fraude não são objetivas - sejam fontes primárias ou denúncias partidárias de peripécias eleitorais" (Lehoucq, 2003:233-34; tradução livre). Além disso, tais informações não tenderiam a captar a fraude em si, mas as alegações de fraude (Dompnier, 2007:127). Como o interesse político por vezes condicionaria a decisão do que seria enquadrado enquanto corrupção eleitoral, dificilmente as informações disponíveis favoreceriam o rigor matemático (idem:124). Aliás, Green (2007) bem alerta: focar as contestações pode subestimar as ocorrências de fraude, visto que potenciais contestantes lidariam com a própria crítica subjetiva dos fatos antes de se decidirem pela apresentação ou não de uma contestação eleitoral ${ }^{29}$. Vê-se, no caso do Brasil republicano, a situação de São Paulo - estado cujas interposições de protestos eleitorais mostraremos ser diminutas, embora não caiba depreender desta baixa incidência ao recurso contestatório a ausência da fraude eleitoral, relatada mesmo em jornais de oposição na época. Por tudo isto, cremos que o melhor uso analítico das petições não seja como proxy da fraude. Daí endossarmos, aqui, a crítica das contestações enquanto tão-somente alegações do fenômeno fraudulento - já 
que a denúncia não pode ser tomada como evidência do acontecimento apontado em si.

A nossa alternativa em fixar os protestos eleitorais como fonte de mensuração das acusações de fraude na Primeira República se mantém mais promissora do que a aposta na sistematização dos registros historiográficos das propaladas fraudes ocorridas - deveras dispersos pela literatura. Ao mesmo tempo, tais documentos nos conduzem ao cerne do problema discutido neste artigo, isto é, encontrar o motivo de o processo eleitoral se fazer alvo de questionamento. Basta lembrar o status das regras previstas para contestar o pleito - baseadas em procedimentos internos ao Congresso Nacional, sem variação de estado a estado, de modo a igualar as formalidades exigidas tanto dos contestantes do Rio de Janeiro quanto dos candidatos do estado do Amazonas. Complementarmente, o próprio fator tempo diminuía os custos de se formalizar um protesto junto à Câmara Baixa: entre o dia da diplomação pelas juntas apuradoras e a data de abertura do Congresso Nacional, quando se iniciava o processo de verificação dos poderes, transcorria, em média, cerca de um mês ${ }^{30}$. Havia prazo suficiente para que os contestantes se organizassem. Por fim, um elemento adicional minimizava consideravelmente o custo de se reclamar: de acordo com o regimento interno da Câmara dos Deputados, o próprio contestante podia apresentar seu protesto diretamente ou por procuração no próprio distrito, sem ir ao Rio de Janeiro ${ }^{31}$.

Para uma compreensão mais minuciosa do caso brasileiro, nos serviremos das contestações apresentadas às eleições compreendidas entre 1900 e 1930, por distritos eleitorais ${ }^{32}$. Nos Anais da Casa localizam-se a íntegra dos documentos, em sua maioria, semimonografias dos litígios eleitorais em nível distrital, em que se trazem referências a fatos dispersos pelas diferentes etapas do processo eleitoral, desde deturpações no alistamento dos aptos a votar até intimidação física na boca da urna, irregularidades na apuração dos votos e na feitura das atas etc. Perfazem-se inclusive dentre o rol de evidências as contracontestações, respostas oferecidas pelos nomes impugnados aos seus contestantes.

Por meio do estudo dos 11 pleitos eleitorais ocorridos entre 1900 e 1930, codificamos cada um dos 495 distritos eleitorais de forma dicotômica, em virtude da presença ou da ausência de impugnação ratificada perante as Comissões de Inquérito no prazo legal. O Gráfico 1 ilustra o percentual de distritos alvo de pelo menos uma denúncia de fraude 
Gráfico 1

Percentual das Contestações por Ano Eleitoral

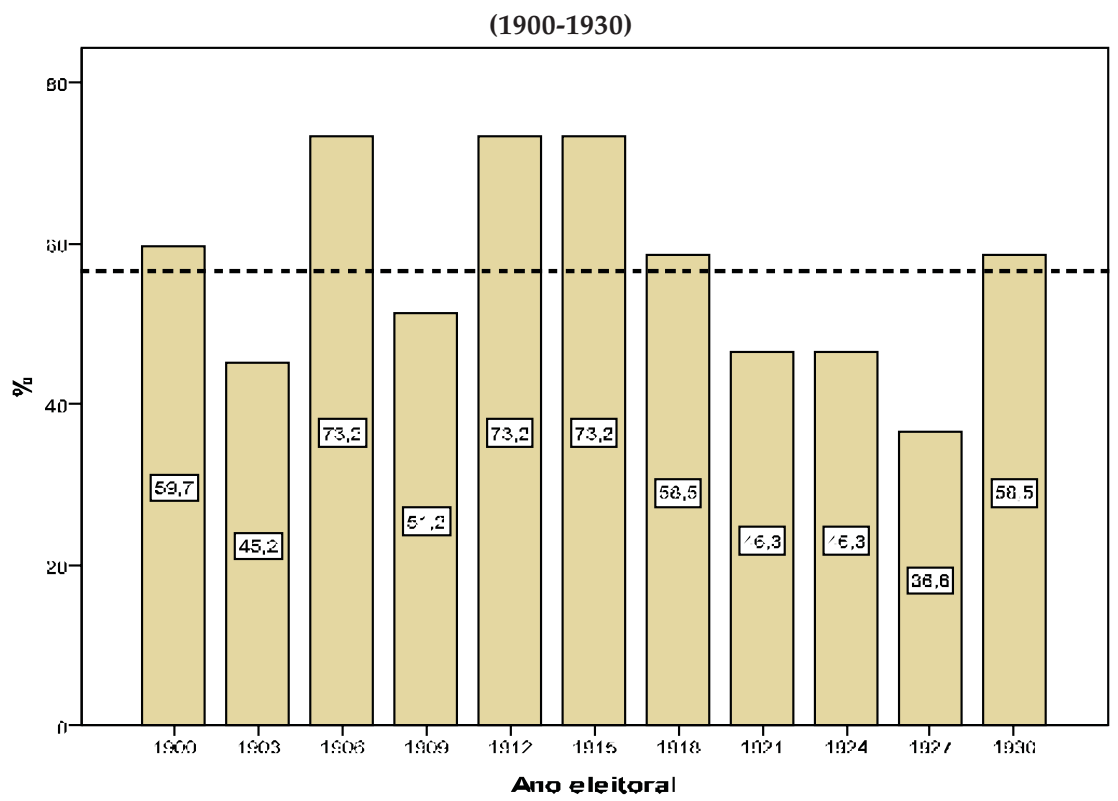

Fonte: Elaboração própria a partir dos Anais da Câmara dos Deputados (ACDs).

eleitoral ${ }^{33}$. Gostaríamos de dar ênfase ao seguinte dado: em média, $56,5 \%$ dos distritos foram sujeitos a alegações do gênero. Trata-se de valor elevado, que atesta a relevância dos protestos formais apresentados à Câmara - um importante meio reivindicatório nas mãos dos políticos na época.

\section{A CAUSA DAS ALEGAÇÕES DE FRAUDE ELEITORAL}

Como explicar o recurso tão usual à contestação dos escrutínios regulares na Primeira República? A resposta encontrada na literatura internacional que aborda o problema da fraude eleitoral nos pleitos do século XIX e início do XX é unívoca a este respeito. Os analistas concordam que a competição eleitoral gera fraude ${ }^{34}$. Especificamente com respeito à nossa adaptação desta abordagem, a sentença pode ser assim reescrita: quanto mais acirrados os certames nas urnas, maior a propensão ao protesto contra o pleito e, no esteio, a generalização das acusações de fraude. O nexo de causalidade é dado. Para adentrar nesta seara, é imperativo definir um modo de dimensionar o nível da competição eleitoral em cada distrito. Daí a definirmos a partir da razão obti- 
da da divisão dos votos do primeiro dos não eleitos (VNE) pelos votos do último dos eleitos (VUE) ${ }^{35}$. Ou seja:

$$
\text { Competição eleitoral (CE) }=(\mathrm{VNE}) /(\mathrm{VUE})
$$

O resultado sempre estará distribuído num continuum que varia entre zero e um. Quanto mais próximo de um, maior a competição política no distrito. Por extensão do raciocínio, quanto mais a razão tender a zero, menor o grau de disputa pelo poder. No período considerado, entre 1900 e 1930, o valor mediano da competição é de 0,61, enquanto equivale a 0,57 a média, sinalizando para pleitos combatidos. O Gráfico 2 representa a incidência de distritos sem alegação de fraude e com fraude denunciada, respectivamente. Diferenças significativas interessantes emergem da comparação entre os dois histogramas. A média da competição eleitoral nos distritos sem acusação de ao menos um

\section{Gráfico 2}

Distritos com e sem Alegação de Fraude

(1900-1930)

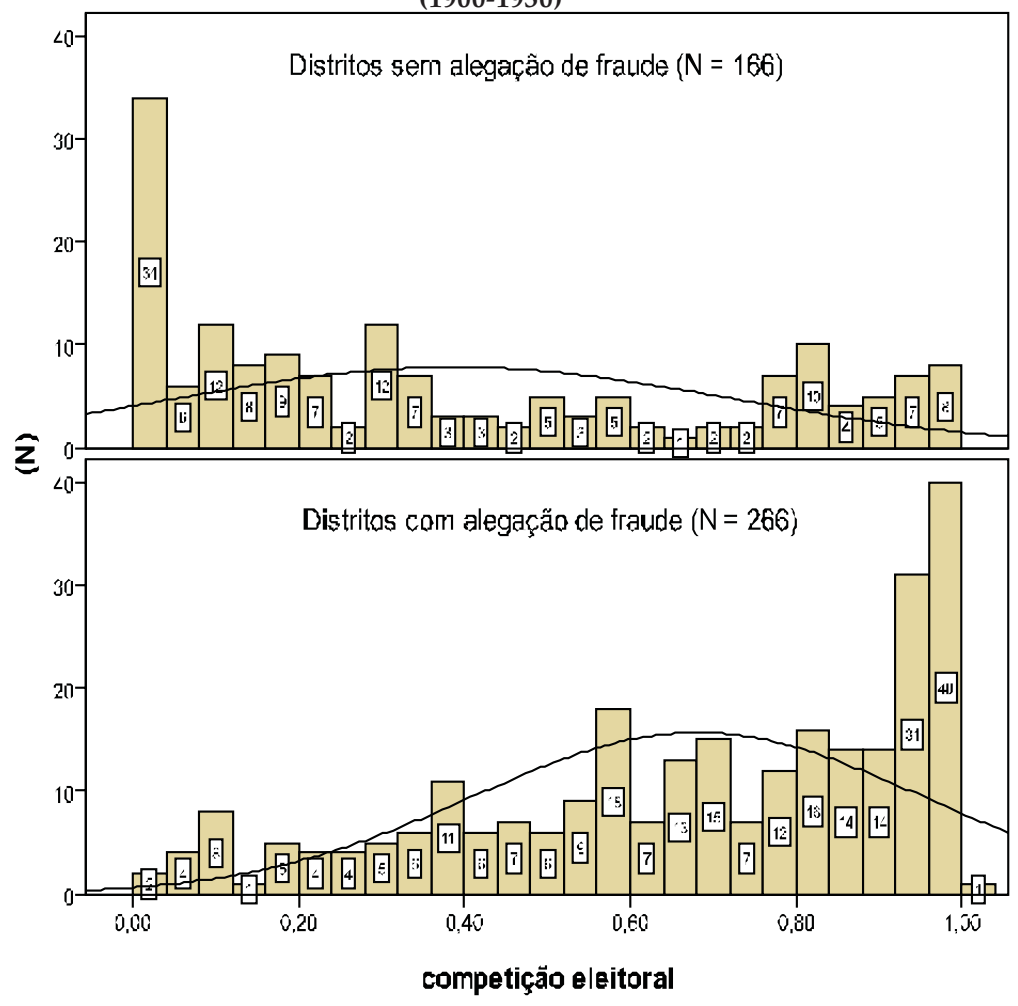

Fonte: Elaboração própria a partir dos $A C D$ s. 
evento fraudulento é 0,39 , subindo para 0,68 nos distritos onde se referem irregularidades no processo eleitoral ${ }^{36}$. Neste último caso, a tendência é clara. Significa que a presença de imputação de um pleito fraudulento depende do nível de competição eleitoral, já que quanto maior, maior a inclinação à denúncia da fraude. Manifesta-se, também no Brasil republicano, o que a literatura internacional tende a defender para outros países - isto é, a concorrência como variável explicativa da delação da fraude, medida por meio dos níveis de contestação. A maioria dos casos $(53,7 \%)$ registra um valor da competição eleitoral superior a 0,70 . Já para os distritos sem queixa de fraude, apesar de os valores medianos terem mostrado níveis inferiores de competição, ressalta-se um grupo de distritos onde a disputa é elevada, mas não se registra contestação da eleição.

Novamente, a questão que se coloca é sobre como compreender este dado. Ainda nos anos 1980, Rodolpho Telarolli apontava que a fraude "só vem à tona em virtude da existência de dissidência no distrito eleitoral, e ao fato de circunstancialmente o resultado ter favorecido inicialmente o candidato independente" (1982:82). É bem plausível, então, supor que os casos de alta competição eleitoral sem queixa de fraude estejam associados mais a situações de disputa entre candidatos pelo mesmo partido. Como a vitória é da legenda, o candidato derrotado não contesta a eleição onde saiu vitorioso seu correligionário - pois não o vê como um competidor, rival, ou mesmo antagonista. Para observar tal conjectura, decidimos identificar o partido pelo qual os candidatos concorreram aos pleitos. Denominamos de competição política interpartidária as observações nas quais o primeiro dos não eleitos e o último dos eleitos estão filiados a legendas diferentes ou quando há um candidato de outra força política que, mesmo com votação inferior ao primeiro dos excluídos, denuncia a fraude. Os demais casos foram definidos de competição intrapartidária, isto é, quando o primeiro dos excluídos é do mesmo partido do último dos eleitos ${ }^{37}$. Os Gráficos 3 e 4 , a seguir, mostram os dados da competição partidária por tipo de distritos.

Desta vez, os histogramas evidenciam que é a disputa interpartidária em litígios acirrados que causa a denúncia da fraude. Quando os mais bem votados são do mesmo partido, dificilmente o provável desconforto pessoal se converte na formalização de contestações - algo verificado em apenas sete distritos. O dado é atraente por dois motivos em particular. Primeiro, porque evidencia o tipo de embate político predo- 
Gráfico 3

Histograma da Competição Eleitoral por Tipo de Competição Partidária em Distritos não Objeto de Denúncia de Fraude

(1900-1930)

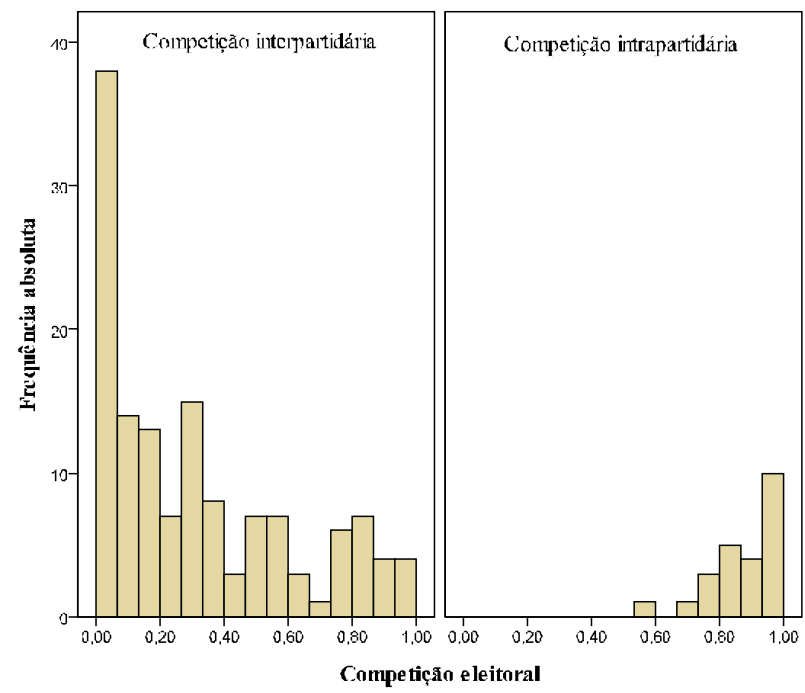

Fonte: Elaboração própria a partir dos ACDs.

Gráfico 4

Histograma da Competição Eleitoral por Tipo de Competição Partidária em Distritos Objeto de Denúncia de Fraude

(1900-1930)

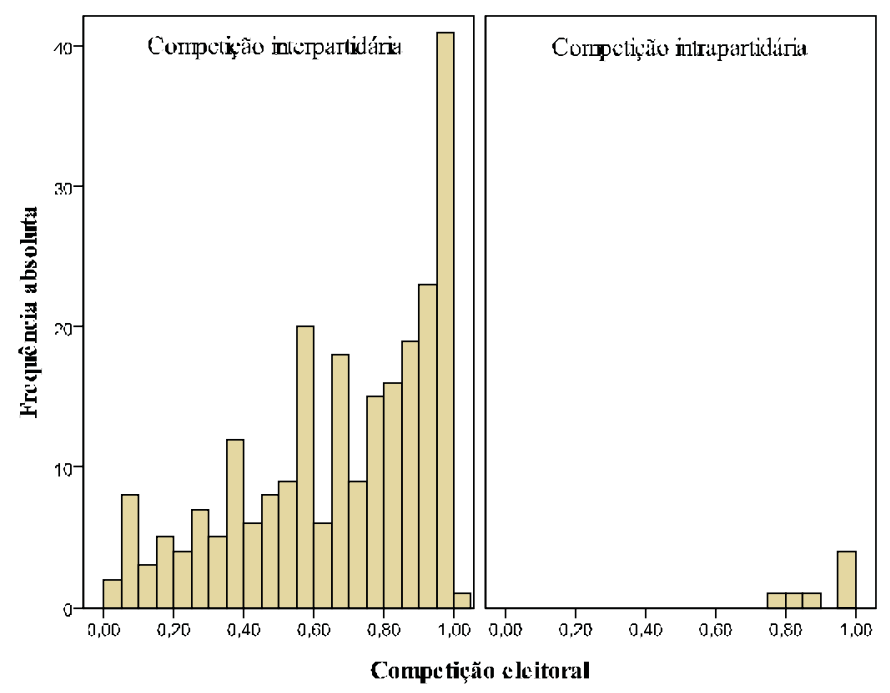

Fonte: Elaboração própria a partir dos $A C D$ s. 
minante na época: aquele travado fora da sigla, entre facções em oposição. Em segundo lugar, o retrato acima esboçado sinaliza para certo grau de fidelidade partidária na era republicana, lançando luz sobre a existência de legendas estruturadas e minimamente organizadas no Brasil dos anos 1900.

Todavia, até agora apresentamos os dados de forma agregada, sem levar em conta a distribuição territorial das alegações de fraude. Se a análise precedente tanto argumentou no sentido de que a competição interpartidária em condições de alta competição eleitoral leva à queixa de episódios fraudulentos, crucial então é saber a geografia do fenômeno. O Gráfico 5 nos ajuda a introduzir o problema. Ele decompõe a incidência das denúncias de fraude para as realidades subnacionais, mantendo a diferenciação pela ocorrência ou não de protestos eleito-

\section{Gráfico 5}

Distribuição das Alegações de Fraude por Estados

(1900-1930)
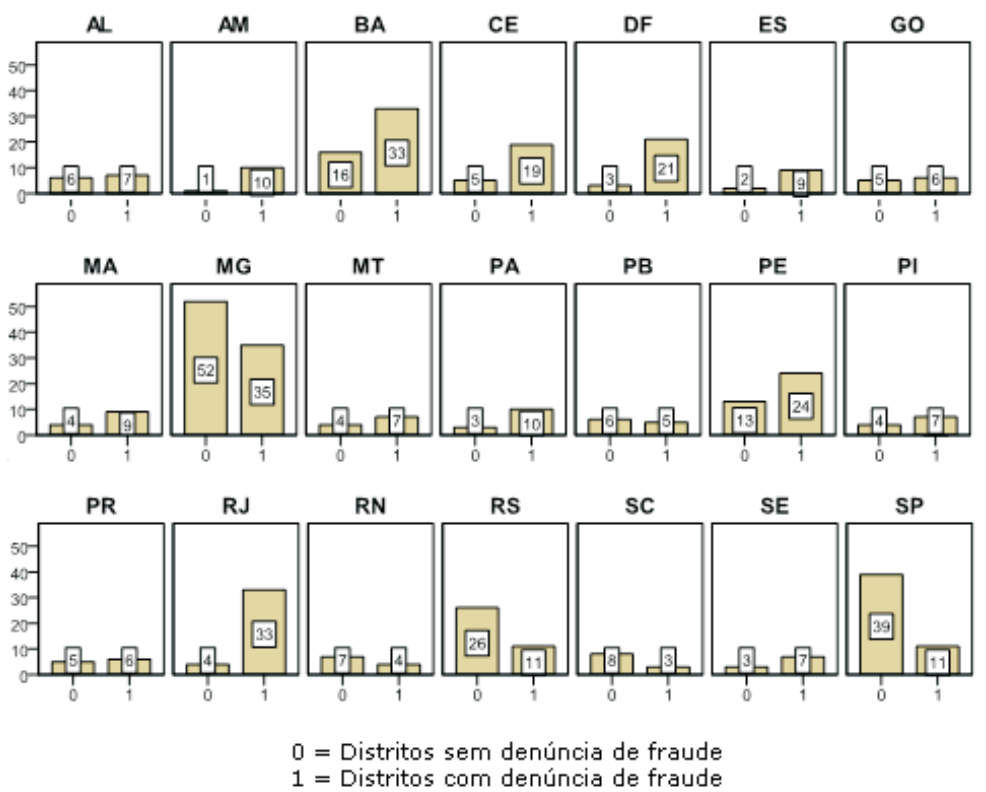

Fonte: Elaboração própria a partir dos ACDs. 
rais. A heterogeneidade decorrente fica, assim, patente, mas podemos perceber a existência de três grupos bem distintos.

No primeiro deles, nenhum dos estados secundários, do ponto de vista socioeconômico ou político, consta entre os casos em que desponta qualquer tendência, seja para o predomínio de distritos com alegações de fraude, seja para a preponderância de distritos não objeto de queixas desta monta (Alagoas, Goiás, Mato Grosso, Paraíba, Piauí, Paraná, Rio Grande do Norte, Santa Catarina e Sergipe). Entretanto, alguns outros, com bancadas estaduais expressivas, distribuem-se por uma das inclinações (Bahia, Pernambuco, Distrito Federal e Rio de Janeiro). Somente as unidades federativas consideradas mais centrais na dinâmica política republicana (São Paulo, Minas Gerais e Rio Grande do Sul) destacam-se como as circunscrições onde as denúncias de fraudes eleitorais eram menores ou quase não tinham lugar. Como explicar tudo isto?

Acreditamos que tal distribuição depende do tipo de configuração político-partidária típica destes grupos. Bahia, Pernambuco, Distrito Federal e Rio de Janeiro encontrariam dificuldade em institucionalizar uma legenda dominante. No solo baiano, o fortalecimento do partido republicano local (PRB) se veria comprometido com a cisão de 1907, de "impacto de longo alcance no futuro do governo de um só partido na política estadual" (Pang, 1979:94; ver também Sampaio, 1975). Também no Rio de Janeiro, "racha" congênere afetaria a consolidação do Partido Republicano Fluminense (PRF), que teria funcionado "praticamente como partido único [somente] até 1897, garantindo a estabilidade da política estadual" (Ferreira, 1994:123). A partir de 1899, o PRRJ entraria em cena, tendo início as querelas entre as duas siglas que acabariam por se enfraquecer mutuamente (ibidem, cap. 6). No Distrito Federal, os partidos "enfrentaram sérias dificuldades na domesticação dos conflitos internos e se viram às voltas com constantes rachas e migrações de seus membros" (Pinto, 2011:233). Mesmo o Partido Republicano Federal de Pernambuco só experimentara uma fase "unipartidária", e a partir de 1911, graças aos percalços dos anos anteriores, marcados pelas interferências federais no estado (Levine, 1980). Em todos estes casos, não seria surpresa o recorrente apelo às contestações e, por conseguinte, à fraude eleitoral-, já que as siglas não dominavam as disputas políticas como desejavam e nem tinham condições reais de fazê-lo, tão frágeis fossem. 
Na contramão, sabe-se da rigorosa estrutura dos partidos republicanos paulista (PRP), gaúcho (PRR) e mineiro (PRM), tradicionalmente citados como os mais organizados na arena eleitoral, controlando o acesso ao mercado político. Sobre São Paulo, diz-se mesmo que a Comissão Central da legenda se empenhava em "reduzir o Partido a uns poucos" (Casalecchi,1987:224; ver também Perissinotto e Sega, 2011). Tanto assim que, na composição das chapas de candidatos, o diretório perrepista acumularia "condições para as prebendas e favoritismos de várias ordens junto aos chefes da política" (Casalecchi,1987:191-192) ${ }^{38}$. Situação correlata encontrar-se-ia no Rio Grande do Sul, com a diferença de que o Partido Republicano Rio-Grandense (PRR) regularia informações até para as próprias assembleias, ignoradas a partir de 1889 (Love, 1975). O caso de Minas Gerais é aparentemente mais complexo, já que registra 35 casos de distritos contestados (40,2\%). Entretanto, são eles concentrados no período 1900-1906 (19 casos) e no ano eleitoral de 1930 (7 casos). O primeiro período coincide com a fase de estruturação e consolidação do PRM. De acordo com a mais extensa pesquisa conduzida sobre o partido mineiro, "pode-se concluir que em 1906 o PRM reduziu-se à sua Comissão Executiva", assumindo o partido o controle da situação (Resende, 1982:189; ver também Figueiredo, 2012). O ano de 1930 é uma situação atípica para Minas. Naquele caso, a Junta Apuradora incumbida de emitir os diplomas aos deputados federais "racha", sem proferir decisão alguma. A situação não se resolve nos dias anteriores à abertura das sessões do Congresso Nacional e o Parlamento será o responsável por definir quais diplomas serão validados. Em geral, pode-se afirmar que os candidatos à representação paulista, gaúcha e mineira evitavam reclamar a validade dos escrutínios em virtude da coordenação eleitoral assegurada pelos partidos republicanos dos respectivos estados. Monopolizando as candidaturas, as legendas garantiam que a competição política se desse entre colegas de chapa, que logicamente descartavam a possibilidade de questionar a eleição de correligionários.

\section{COMPETIÇÃO POLÍTICA PARA QUÊ?}

Resta-nos entender as razões das disputas travadas nos estados, que levavam as oposições a denunciar as fraudes eventualmente cometidas nas diferentes etapas do processo eleitoral republicano. Nesta empreita, outra vez faremos uso das contestações, embora recaindo agora sobre o conteúdo delas como objeto de investigação. Dos 11 pleitos regulares para preenchimento das cadeiras da Câmara Federal ocorridos 
entre 1899 e 1930, escolhemos cinco anos eleitorais, contabilizando um total de 175 contestações e 78 contracontestações. São eles: 1900, 1903, 1912, 1918 e 1927. A escolha dos casos não limita nossa capacidade de generalização, dado que o recorte é representativo dos demais pleitos. Como já antecipamos, tais protestos seguiam regras uniformes, previstas no regimento interno da Câmara e mantidas intactas ao longo dos anos. Ademais, os cinco anos escolhidos dão conta das mudanças na lei eleitoral. Em 1900 e 1903, as disputas incidem sob a vigência da primeira norma eleitoral republicana - a Lei no 35, de 1892. Introduzida em 1904, a Lei Rosa e Silva governa os escrutínios de 1912. Os pleitos de 1918 e 1927 se norteiam pela norma jurídica no 3.208, aprovada em 1916. Não é o caso, aqui, de distinguir o conteúdo das inúmeras denúncias apresentadas em cada uma delas. Interessa-nos, ao contrário, enfatizar somente um ponto, que cintila tão logo se avance na leitura das contestações e de suas respectivas refutações. O conjunto dos relatos indica que a intimidação física e a corrupção não se faziam condições suficientemente capazes de manter sob controle o resultado das urnas. Era, antes, o domínio partidário da máquina administrativo-eleitoral, entendida aqui como a estrutura organizacional necessária à realização dos escrutínios segundo as prescrições legais da época, a melhor aposta no intento de se diminuir a incerteza dos pleitos que se seguiram. O poder de mando sobre pelo menos três das etapas burocráticas necessárias à viabilização destes litígios - a provisão do alistamento e qualificação dos eleitores (1), a composição das mesas eleitorais (2) e a contagem dos votos nas seções e nas Juntas Apuradoras (3) - condicionava saída menos custosa para as forças políticas e muito nos informa a respeito do modus operandi dos pleitos republicanos.

No que tange às críticas desferidas ao alistamento, a tentativa de anulação da competição política antes das próprias eleições terem lugar perfaz lugar-comum nas acusações voltadas aos procedimentos adotados durante a qualificação dos aptos a votar. As narrativas mostram como esta fase de definição do eleitorado passa a ser percebida enquanto processo coletivo que, mesmo organizado pelos recursos humanos previstos em lei, estruturava-se, em última instância, via partidos políticos - os atores capazes de controlar a burocracia eleitoral em questão. É no alistamento que se manifestava o primeiro momento da luta entre governistas e oposicionistas. Mesmo que tentasse, o cidadão se via à mercê das possíveis barreiras interpostas pelas forças situacionistas que controlavam o ingresso no mercado eleitoral. As normas legais que definiam os critérios para a manifestação efetiva do direito ao 
voto não bastavam, por si só, para garantir o registro ao eleitor. A concessão do título eleitoral era, antes, resultado de um processo ordenado e apoiado pelas legendas em conúbio com os atores administrativos incumbidos de alistar o povo pela legislação vigente. Defendendo os diplomas de seu grupo governista, vitorioso, um candidato era taxativo: "si os candidatos da chapa e os candidatos avulsos do nosso partido venceram foi porque a minoria [...] não cuidou do alistamento" (ACD, 30/4/1918:289).

Em consonância, os protestos apontam a interferência das legendas partidárias ainda numa segunda etapa do processo eleitoral, igualmente pertinente ao controle do voto: a composição das mesas eleitorais. São comuns os relatos das lutas travadas entre diferentes facções pela constituição de mesas unânimes. O objetivo era viabilizar o domínio da condução dos escrutínios no dia do pleito. Afinal, conformações do gênero configuravam garantia da exclusão dos eleitores de oposição (pela recusa de seus títulos) e da admissão de correligionários da mesa previamente excluídos do alistamento ( $A C D, 15 / 5 / 1912: 692)$. Da mesma forma, anulava-se a possibilidade da denúncia da fraude pelos oposicionistas (cf. $A C D, 4 / 5 / 1903: 176)$, facilitando, assim, a redução de certos custos arcados pelos partidos, como a compra de votos através de vários tipos de suborno ( $A C D$, 30/4/1918:263). Uma mesa unânime também tornava mais simples a apuração dos votos na seção imediatamente após o encerramento do pleito, terceira etapa do processo eleitoral. Sem opositores, os escrutinadores podiam "contar a modo próprio", eventualmente ajustando os resultados para favorecer alguns candidatos ou forjando atas falsas, na famosa lógica do bico de pena. As críticas ao falseamento das eleições ainda recaíam sobre os trabalhos das Juntas Apuradoras, responsáveis pela contagem dos votos e entrega dos diplomas aos eleitos.

De fato, o estudo qualitativo das contestações ilumina a relevância do monopólio partidário sobre o aparato administrativo-eleitoral, desde o serviço de alistamento até a fase de apuração dos votos nas próprias seções e, sucessivamente, nas Juntas Apuradoras - privilégio que ofertava garantias de sucesso eleitoral. Elucidativos desta conotação dos pleitos republicanos se fazem alguns testemunhos da época, oferecendo, por vezes, verdadeiro balanço das razões da vitória dos concorrentes. Contestando o pleito de Alagoas, a chapa de oposição assim se manifestava: 
Concorremos às eleições federais em Alagoas como candidatos de oposição a um partido que está na posse de todas as posições oficiais. [...] E enquanto para nos se manteve, desde o serviço de alistamento até a consumação do processo eleitoral, esse estado de francas hostilidades por parte da maioria dos agentes da execução da nova lei e de todos os que exerciam qualquer parcela de autoridade nos municípios do interior, os nossos adversários, dispondo do aparelho administrativo estadual e municipal, tinham campo aberto à prática de todas as medidas que podiam facilitar-lhes a adulteração da lei em auxilio de sua causa (ACD, 6/5/1918:200).

O protagonismo dos recursos disponíveis no âmbito das municipalidades fica mesmo patente na refutação formulada pela chapa diplomada, no Piauí, à contestação que recebeu de um candidato não eleito.

A influencia e o predominio na representação e no governo municipal, a posse, em definitivo, dos elementos que constituem a administração politica e governamental dos municipios, e para os partidos que conseguem adquiril-a e mantel-a, são não só a prova irrefragavel da sua força, da sua pujança, da sua superioridade numerica, mas também a garantia da sua victoria nos pleitos eleitoraes, dado o regimen eleitoral que adoptamos ( $A C D, 28 / 5 / 1900: 255)$.

Tudo exposto torna-se inevitável repensar a manifestação da fraude eleitoral na experiência republicana. Não cabe mais interpretar o controle sobre a máquina administrativa que respaldava a execução dos pleitos como prática fraudulenta em si. Afinal, há elementos empíricos suficientes sinalizando para o fato da fraude se manifestar de forma contundente quando o domínio do aparato burocrático atrelado à realização dos escrutínios, normalmente imperfeito, se mostrava ainda mais falho. À hegemonia partidária registrada em alguns estados, como São Paulo, Minas Gerais e Rio Grande do Sul, contrapunha-se a ausência de real poder de mando noutras realidades, como Rio de Janeiro e Bahia. Era nestes últimos casos que a fraude se tornara necessária e preponderante na dinâmica eleitoral da República, endossados todos os estratagemas possíveis para se condicionar, a tempo, o resultado final. Em suma, como afirmou um contestante da época, a fraude era o "último recurso da salvação" ( $A C D, 24 / 4 / 1927: 216)$ ou, ainda, como também lembrava Victor Nunes Leal, "recorre-se à violência quando outros processos são mais morosos, ou ineficazes, para o fim visado" (1997:68). Dito de outro modo: a princípio, destaque para o primor pelo controle sobre a burocracia eleitoral. Ao falhar deste me- 
canismo, a opção pelo exercício das práticas fraudulentas se fazia ordinária.

\section{CONCLUSÃO}

Organizado em torno da análise das contestações apresentadas pelos candidatos derrotados nos escrutínios para renovação da Câmara Baixa entre 1900 e 1930, este artigo encampa a necessidade de romper com as leituras convencionais sobre as eleições na Primeira República. Nesta perspectiva, apresentamos algumas considerações finais em caráter positivo, bradando pela revisita ao período no esteio da defesa de um programa de pesquisa dedicado a repensar o regime representativo no Brasil.

A primeira reflexão é elementar: o âmbito em que se decidiam as eleições era o municipal. Ninguém melhor do que Victor Nunes Leal tem enfatizado este ponto ${ }^{39}$. Entretanto, ainda não se encontravam plenamente detalhadas as razões do protagonismo das municipalidades no contexto da dinâmica eleitoral. Através do estudo sistemático dos protestos formais aos pleitos republicanos, pudemos compreender como se fazia central o controle sobre as fases preliminares dos escrutínios (como o alistamento e a organização das mesas eleitorais) para a definição das eleições - etapas todas restritas ao domínio local. Vimos como as demais fases também se mostravam relevantes, porém servindo mais para reter e anular os eventuais opositores políticos eventualmente capazes de alcançar êxito nas fases anteriores.

Em segundo lugar, merece ser frisado: a prática da fraude deve ser entendida por além do tema do desvirtuamento da verdade eleitoral. É fato que a literatura dedicada ao exame da Primeira República se empenhou em tornar pejorativa a forma de competição em época republicana. Neste artigo, entretanto, mostramos que a importância das práticas de deturpação do voto deveriam ser repensadas, enquadrando-as num modo de competir em voga naquele momento. Isso não significa menosprezar a fraude, mas reconduzi-la ao tema da incapacidade de controle sobre a máquina administrativa dos pleitos. Segue-se dessa consideração que o problema da dinâmica eleitoral em época republicana precisaria se desvincular das interpretações sociológicas clássicas, que atribuem às características atrasadas da sociedade brasileira o formato não competitivo das eleições no período. Decerto, o ponto não é se as eleições eram facciosas e arbitrárias - mas outro, de cunho institucio- 
nal. Em fins do século XIX e início do XX, os escrutínios terminantemente embargavam mais diante dos impasses desencadeados pelo controle dos mecanismos eleitorais do que pelas dificuldades de se conter o eleitorado. O tema não é novo nas análises sobre os outros países latino-americanos e remete à noção de "gobiernos electores" ${ }^{40}$, isto é, ao fato de que a competição girava em torno da condução da burocracia eleitoral. Ao que tudo indica, a fraude configurava um último recurso para controlar o voto - seguramente não o mais comum. Neste artigo, focamos as contestações como forma de mapear as alegações de fraude. Outras fontes - como os jornais da época -, precisariam ser investigadas para tratar do fenômeno. É desta forma que poderemos ter uma visualização mais completa do fenômeno e evitar possíveis equívocos.

Outro elemento digno de reconsideração diz respeito à própria caracterização das eleições ocorridas nos anos 1900. Não é mais possível desqualificar o papel dos escrutínios em época republicana, enfatizando a estagnação da vida representativa no país ou ignorando as vicissitudes políticas dos estados, onde reinaria a "ausência quase absoluta de competição partidária" (Motta, 2008:43; ver também Melo, 2007 e Lessa, 1988). Os dados aqui levantados apontam para a existência de certo grau de dissenso interoligárquico, que girava em torno das eleições e se canalizava, sobretudo, através da mediação dos partidos políticos ${ }^{41}$. Futuras pesquisas deveriam suplantar a imagem de sistemas partidários estaduais unipartidários, investindo na reunião e circulação de provas relativas às eventuais mudanças oligárquicas na gestão do poder via escrutínios ${ }^{42}$, bem como refletir sobre o nível de organização das máquinas partidárias.

A nosso entender, um melhor entendimento dos pleitos na época perpassa por uma investida crítica no estudo do papel dos atores centrais em jogo, como os partidos e as próprias instituições - em detrimento do aprofundamento usual na discussão da vontade dos indivíduos e na própria questão da cidadania. Aliás, o debate circunscrito ao desenvolvimento da cidadania parece ter assombrado os analistas da Primeira República. Decididamente, está na hora de se desapegar desta reflexão e reconhecer que a explanação das eleições se traduz na observação das práticas eleitorais - e, decerto, não se dará na ênfase sobre a ausência dos direitos políticos no período. Importa compreender a natureza formal da nossa representação política, e não alimentar um ressentimento por aquela que nunca tivemos. Como lembrou recente- 
mente Wanderley Guilherme dos Santos, a experiência republicana fornece "uma excepcional base histórica para a investigação do modus operandi dos sistemas oligárquicos e da vida política real da Primeira República, tanto quanto possível livre dos preconceitos de que as elites que a sucederam a cobriram" (2013:34). Toda a discussão precedente reitera a conveniência de um esforço reflexivo imediato que dê a devida dignidade temática às eleições e à competição partidária na Primeira República. Em definitivo, o voto constituía o alicerce do jogo político republicano, facultando a racionalização dos conflitos entre as próprias elites locais.

(Recebido para publicação em outubro de 2013) (Aprovado para publicação em janeiro de 2014) 


\section{NOTAS}

1. É sintomático Jairo Nicolau poder tranquilamente afirmar, na sua obra mais recente, publicada em pleno 2012, a ausência de "estudos sistemáticos sobre as fraudes eleitorais" supostamente correntes nos anos 1900 (Nicolau, 2012:69). Aliás, a lacuna se mostra muito maior, estendendo-se mesmo ao processo eleitoral como um todo. Faltam informações mínimas para o período, tais como o número de eleitores e as taxas de comparecimento eleitoral. Na verdade, sequer são conhecidos os resultados dos escrutínios federais para renovação da Câmara e do Senado. Com efeito, constitui exceção importante para a história republicana o trabalho de Claudia Viscardi, que desmitifica a ideia de uma relação estável entre São Paulo e Minas Gerais via análise do processo de escolha das candidaturas presidenciais (Viscardi, 2012).

2. No texto, os termos contestação, petição, protesto oficial e queixas formais são todos intercambiáveis.

3. Os deputados exerciam o mandato por três anos, os senadores por nove e o presidente da República era eleito diretamente a cada quatro anos. Na ausência da previsão legal de definição de suplentes nos próprios pleitos regulares, escrutínios complementares eram convocados para todos os cargos sempre que se verificassem novas vacâncias.

4. Respaldamos a descrição que segue somente nas leis principais, que abarcam cada uma das etapas do processo eleitoral no regime republicano - a saber: as normas $n \underline{0}$ 35 (de 1892), no 1.269 (de 1904) e no 3.208 (de 1916), na medida em que as outras leis deste teor promulgadas na época ocupavam-se de aspectos específicos, sem alterar substancialmente os escrutínios.

5. Cf. a Lei no 35/1892, cap. II. Cabe pontuar que a lei previa tanto a divisão do município em seções quanto a eleição das comissões seccionais unicamente pelos membros do governo municipal na eventual falta absoluta dos seus imediatos em votos (idem, art. $\left.3^{\circ}\right)$.

6. Para sermos mais exatos, "presidente do governo municipal" era o termo usado na época para o equivalente do prefeito dos dias correntes. Como o leitor notará, tendemos a atualizar o vocábulo no curso do texto, apesar dos termos se mostrarem absolutamente intercambiáveis.

7. Pela Lei Rosa e Silva, o alistamento torna-se incumbência anterior à divisão dos municípios em seções eleitorais, apesar desta segunda atividade continuar a cabo da comissão especial de alistamento (art. 26).

8. Antes disso, o serventuário de justiça somente era chamado na qualidade de escrivão das atas das comissões de alistamento e papéis congêneres às mesmas, se necessário (Lei n으 35/1892, cap. II, art. 11으).

9. Mais exatamente, era definida a competência tanto pela convocatória quanto pela presidência da comissão de alistamento ao juiz designado pelo presidente do Tribunal de Justiça do Estado quando o município gozasse de outro (ou vários) juiz (juízes) de direito (Lei $\mathrm{n}^{\mathrm{o}} 1.269 / 1904$, art. $8^{\underline{0}}, \S^{1} 1^{\circ}$ ). A lei ainda previa encargo correlato ao juiz estadual de "mais elevada categoria" naqueles municípios que não eram sede de comarca (idem, $\S 1^{\circ}$ ). Assim, o ajudante do procurador da República ficava resguardado para tal empreita somente nos municípios onde inexistisse autoridade judiciária es- 
tadual (§ $\left.3^{\circ}\right)$. Por fim, cabia ao presidente do Tribunal Civil ou Criminal a empreita no Distrito Federal $\left(\S 4^{\underline{o}}\right)$.

10. O custo para um cidadão pleitear a inclusão no alistamento eleitoral aumenta consideravelmente a partir da reforma de 1904. Segundo a norma anterior, bastava comprovar a maioridade civil (fixada em 21 anos) e a condição de alfabetizado para encaminhar o pedido de qualificação (Lei no 35/1892, art. 16).

11. Lei $\mathrm{n}-1.269 / 1904$, art. 17. E não para por aí: a prova de residência teria de ser atestada por qualquer autoridade judiciária ou policial do respectivo município. Em caso de recusa, caberia declaração de três cidadãos comerciantes ou proprietários, residentes no mesmo município (idem, art. 18, § $3^{\text {}}$ ).

12. Tanto a lei eleitoral de 1892 (art. 39) quanto a reforma de 1904 (art. 26) discriminavam a seleção dos edifícios que sediariam as votações como encargo das comissões de alistamento.

13. Lei $\mathrm{n}^{\mathrm{O}} 1.269 / 1904$, art. 61 . O seu parágrafo $1^{\mathrm{O}}$ determinava funcionar o $1^{\mathrm{o}}$ procurador seccional, no Distrito Federal, e o procurador da República, na capital dos Estados.

14. Os termos "mesários" e "escrutinadores" são usados de forma intercambiável neste texto.

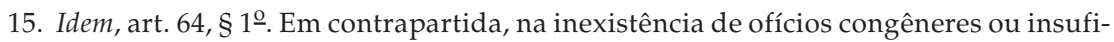
ciência numérica dos mesmos para a composição integral de cada mesa seccional, estava a junta eleitoral habilitada a proceder à eleição daqueles corpos, integral ou parcial, respectivamente (idem, art. 66). A lei anterior já permitia a entrada de eleitores para completar a mesa quando um ou dois dos escrutinadores regularmente eleitos não comparecessem até o início dos trabalhos de apuração da ata da sessão, ao final da votação (Lei no 35/1892, art. 43, §1으). Entretanto, foi com a Lei Rosa e Silva, em 1904, que se apresentou a possibilidade de incorporação de eleitores dentre os mesários independentemente das contingências inerentes ao andamento do pleito em cada seção.

16. O mesmo ocorre nas sedes dos termos judiciários. Somente em municípios que não eram termos judiciários é que se levavam em conta a preferência de um eleitor apresentado em ofício ao juiz de direito por eleitores da seção, além das demais seções das sedes dos municípios e nas outras dos distritos de paz, onde se tomavam os votos de três eleitores indicados na escolha dos escrutinadores seccionais (idem, art. 9으).

17. Em seu art. $8^{\circ}$, a Lei $\mathrm{n}-3.208$ / de 1916 recomendava a instalação, na sede de cada município, de "tantas mesas eleitoraes quantos forem os tabelliães e officiaes do Registro Civil"; e "na de cada districto de paz ou sub-divisão judiciaria apenas uma".

18. A Lei $\mathrm{n}$-3.208/1916 inovava ainda ao estabelecer que a presidência da Junta Apuradora fosse um juiz federal, auxiliado na apuração pelo representante do Ministério Público junto ao Tribunal Superior de Justiça. Este era o primeiro passo em direção ao reconhecimento do Poder Judiciário como autoridade incumbida de apurar as eleições - algo que seria mais tarde introduzido no Código Eleitoral de 1932.

19. Cf. Constituição da República dos Estados Unidos do Brasil de 1891, art. 18.

20. É importante lembrar que a Constituição imperial de 1824 igualmente apontava os regimentos internos de cada casa como norteadores da verificação dos poderes na época - e foi exatamente observada nestes termos a certificação eleitoral durante o Império. 
21. Este método estava circunscrito à comissão denominada, de forma genérica, de "Comissão de Verificação de Poderes".

22. Vale lembrar, porém, que este modelo de reconhecimento dos diplomas não era invenção brasileira, mas a característica de todos os parlamentos do século XIX. Para mais detalhes sobre o ponto, ver Ricci e Zulini (2013).

23. Não se admitia, porém, a participação do deputado na comissão incumbida de analisar as eleições do estado em que fora eleito. O número das Comissões de Inquérito foi de cinco até 1904, passando para seis com a promulgação da Lei Rosa e Silva.

24. Realmente, muito embora a lei previsse a apresentação de recursos ao alistamento, dando margem à sua contestação e limitando, em tese, o seu controle pleno por parte dos encarregados desta definição dos qualificados ao exercício do voto, a possibilidade de protestar inclusões e não inclusões se deparava com as várias dificuldades impostas pelos trâmites burocráticos, além das limitações de infraestrutura comuns à maioria dos municípios na época. Isto porque as reclamações, uma vez aceitas pelas comissões seccionais, deviam ser despachadas para uma junta eleitoral, que funcionava apenas na capital dos Estados e era composta pelo juiz seccional, seu substituto e o procurador seccional. De registro e expedição compulsória por parte do juiz seccional, os recursos dependiam da entrega via agência dos Correios, sabidamente ausentes em grande parte das municipalidades do Brasil republicano (Lei no 35/1892, cap. IV).

25. A Lei no 35/1892 não impunha limites concretos à escolha dos prédios privados como locais de votação, "comtanto que estes fiquem equiparados aos publicos durante o processo eleitoral" (art. 39). Adotam-se medidas cautelares, na verdade, a partir da reforma de 1904, que admite o uso de locações particulares apenas na inexistência de edifícios públicos (Lei nํㅗ 1.269/1904, art. 26, § 3으).

26. Como a fase inicial de apuração se dava logo após a votação ser encerrada, a literatura normalmente não dissocia ambas as etapas ao tratar dos casos de fraude eleitoral. A praxe é manter a menção ao momento da votação.

27. Yves Meny argumenta na mesma linha. Nas suas palavras, "Por definição, a corrupção é um intercâmbio oculto, secreto que fornece acesso aos recursos que o respeito por regras e procedimentos não teria permitido obter ou teria feito ao acaso. Esta opacidade do comércio torna extremamente difícil a mensuração desse fenômeno empírico, uma vez que apenas alguns casos criminais vêm à luz" (Meny, 1992:241; tradução livre). Daí ser comum encontrar fraude sem ter meios de apontar seus autores (Dompnier, 2007:126).

28. Para uma revisão mais abrangente da literatura dedicada a fraude eleitoral, ver Lehoucq (2003).

29. Basicamente, considerariam os custos de levar adiante uma reclamação eleitoral e a consequente chance de êxito neste desafio (neste caso, dependendo, por exemplo, da esperada intercessão da maioria no processo de reconhecimento) como, também, o valor atribuído, individualmente, ao assento no Congresso.

30. Enquanto o Congresso Nacional se reunia, provisoriamente, em abril, as eleições para a Câmara dos Deputados e a renovação do terço do Senado Federal ocorreram bem antes. As eleições estudadas neste artigo ocorreram nas respectivas datas: 31/12/1899; 18/2/1903; 30/1/1906; 30/1/1909; 31/1/1912; 30/1/1915; 1/3/1918; 20/2/1921; 17/2/1924; 24/2/1927; 1/3/1930. 
31. Segundo o Regimento Interno da Câmara aprovado em 1891, os relatores das comissões de inquérito, uma vez informados do teor dos documentos referentes aos escrutínios, convidariam "os interessados, seus advogados ou procuradores, para oferecerem as suas exposições a respeito do processo eleitoral unicamente" (RICD, 1891, art. 7, § $2^{\mathrm{O}}$, ênfase nossa).

32. Infelizmente, os relatórios das Comissões de Inquérito lavrados na Câmara Baixa não apresentam documentos completos para os pleitos ocorridos em 1894 e 1897, impedindo a comparação do volume de contestações formalizadas para ambas as eleições. Aproveitamos ainda para apontar que nosso estudo contempla apenas as eleições regulares, e não as suplementares, realizadas em caso de renúncia ou falecimento de um representante, quando era necessário convocar novo pleito para ocupação da cadeira vacante.

33. A partir de agora, os termos contestação, petição, protesto oficial e queixas formais passam a ser intercambiáveis ainda com denúncias e alegações de fraude.

34. Sobre o nexo de causalidade entre competição partidário-eleitoral e fraude, ver a discussão presente em Lehoucq (2003).

35. A decisão de medir a competição desta forma deriva da dificuldade de coleta de dados e informações para todos os candidatos. Mesmo assim, conseguimos os votos para os primeiros dos não eleitos e o último dos eleitos de 432 distritos, restando 63 missings. Para uma discussão metodológica sobre a decisão de operacionalizar a competição eleitoral nestes termos e os problemas na coleta dos dados, remetemos ao Apêndice deste artigo.

36. Considerando a variação nos dados e os valores extremos significativos, uma média mais "robusta" da média aritmética seria a mediana - que, no caso dos distritos sem fraude é 0,31, passando para 0,74 no caso de distritos fraudados.

37. Para detalhamento da compilação dos resultados eleitorais nos distritos como a realizamos, remetemos às considerações contidas no Apêndice.

38. Isso não significa desconhecer as inúmeras dissidências pelas quais passou o PRP durante a Primeira República (Woodard, 2005). Todavia, nossos dados mostram que tais divergências internas não chegaram a subtrair do referido partido o controle da dinâmica eleitoral que conduzia com mão de ferro.

39. A respeito das interpretações de Leal sobre as eleições ver, por último, as reflexões de Limongi (2012).

40. Posada-Carbó (2000) é referência obrigatória para uma discussão aprofundada deste tópico.

41. Em artigo recente, Wanderley Guilherme dos Santos endossa direção correlata, mesmo indiretamente, ao constatar a baixa taxa de reeleição na Câmara Federal, "posto que os senhores locais destituíam de poder qualquer representante" (Santos, 2013:16).

42. O esforço é certamente enorme na medida em que as disputas políticas se travarem dentro dos estados - e não no plano nacional. Isto obriga o redirecionamento da atenção para a dinâmica partidária interna a cada um dos 22 estados que compunham a federação. Recomendamos, a título de inspiração, os trabalhos existentes para o caso do Rio de Janeiro e do Distrito Federal (Freire, 2000; Pinto, 2011; Veneu,1987). 


\section{REFERÊNCIAS BIBLIOGRÁFICAS}

ANAIS DA CÂMARA DOS DEPUTADOS (1900-1930). Disponível em http:/ /imagem. camara.gov.br/pesquisa_diario_basica.asp.

ANDERSON, Margret Lavinia. (2000), Practicing Democracy: Elections and Political Culture in Imperial Germany. Princeton, Princeton University Press.

ANDREUCCI, Franco. (1995), “La Norma e la Prassi. Le Elezioni Irregolari nell'Italia Liberale, 1861-1880". Passato e Presente, vol. 34, pp. 39-78.

CARONE, Edgard. (1972), A República Velha (Instituições e Classes Sociais). São Paulo, Difusão Europeia do Livro.

CARVALHO, José Murilo de. (2003), “Os Três Povos da República”. Revista USP, vol. 59, pp. 96-115.

CASALECCHI, José E. (1987), O Partido Republicano Paulista: Política e Poder (1889-1926). São Paulo, Editora Brasiliense.

CHARNAY, Jean Paul. (1964), Les Scrutins Politiques en France de 1815 à 1962: Contestations et In-validations. Paris, Librairie Armand Colin.

CONSTITUIÇÃO DA REPÚBLICA DOS ESTADOS UNIDOS DO BRASIL DE 1891. Publicada no Diário do Congresso Nacional de 24/2/1891. Disponível em http:/ / www2.camara.leg.br/legin/fed/consti/1824-1899/constituicao-35081-24fevereiro-1891-532699-publicacaooriginal-15017-pl.html.

DOMPNIER, Nathalie. (2007), “La Mesure des Fraudes Électorales. Difficultés Méthodologiques et Enjeux Politiques". Histoire \& Mesure, vol. XXII, no 1.

EISENSTADT, Todd. (2002), “Measuring Electoral Court Failure in Democratizing Mexico". International Political Science Review, vol. 23, no 1, pp. 47-68.

FAORO, Raymundo. (2001), Os Donos do Poder. Formação do Patronato Político Brasileiro (3a ed.). Rio de Janeiro, Globo.

FERREIRA, Marieta de Moraes. (1994), Em Busca da Idade de Ouro: As Elites Políticas Fluminenses na Primeira República (1889-1930). Rio de Janeiro, Editora UFRJ.

FIGUEIREDO, Vitor Fonseca. (2012), “A Marginalidade da Representação Política do Norte de Minas Gerais na Bancada Parlamentar Mineira durante a Primeira República". Opsis, vol. 12, no 1, pp. 164-180.

FREIRE, Américo. (2000), Uma Capital para a República: Poder Federal e Forças Políticas Locais no Rio de Janeiro na Virada para o Século XX. Rio de Janeiro, Revan.

GREEN, Mathew. (2007), "Race, Party, and Contested Elections to the U.S. House of Representatives". Polity, vol. 39, no 2, pp. 155-178.

KAM, Christopher. (2007), Four Lessons about Corruption from Victorian Britain. Trabalho apresentado no workshop Corruption and Democracy, University of British Columbia, Vancouver, BC, 8-9 de junho.

KINZO, Maria D’Alva Gil. (1980), Representação Política e Sistema Eleitoral no Brasil. São Paulo, Edições Símbolo. 
LEAL, Victor Nunes. (1997), Coronelismo, Enxada e Voto (3a ed.). São Paulo, Editora Alfa-Ômega.

LEHOUCQ, Fabrice Edouard. (2003), “Electoral Fraud: Causes, Types, and Consequences". Annual Review of Political Science, vol. 6, pp. 233-256.

LESSA, Renato. (1988), A Invenção Republicana. Rio de Janeiro, Vértice.

LEVINE, Robert M. (1980), A Velha Usina: Pernambuco na Federação Brasileira (1989-1937). Rio de Janeiro, Paz e Terra.

LIMA JUNIOR, Olavo Brasil de. (1999), "Eleições Presidenciais: Centralidade, Contexto e Implicações". Revista Brasileira de Ciências Sociais, vol. 14, no 40, pp. 11-30.

LIMONGI, Fernando. (2012), “Eleições e Democracia no Brasil: Victor Nunes Leal e a Transição de 1945". DADOS - Revista de Ciências Sociais, vol. 55, no 1, pp. 37-69.

LOVE, Joseph. (1975), O Regionalismo Gaúcho e as Origens da Revolução de 1930. São Paulo, Perspectiva.

MENY, Yves. (1992), La Corruption de la République. Paris, Fayard.

MELO, Carlos Ranulfo. (2007), “Nem tanto ao Mar, nem tanto a Terra. Elementos para uma Análise do Sistema Partidário Brasileiro", in C. R. Melo e M. A. Sáez (orgs.), A Democracia Brasileira. Balanço e Perspectivas para o Século 21. Belo Horizonte, UFMG Editora, pp. 267-302.

MOTTA, Rogério Patto. (2008), Introdução à História dos Partidos Políticos Brasileiros. Belo Horizonte, UFMG Editora.

NICOLAU, Jairo. (2012), Eleições no Brasil. Do Império aos Dias Atuais. Rio de Janeiro, Zahar.

PANG, Eul- Soo. (1979), Coronelismo e Oligarquias, 1889-1943. A Bahia na Primeira República Brasileira. Rio de Janeiro, Civilização Brasileira.

PERISSINOTTO, Renato e SEGA, Rafael Augustus. (2011), “Republicanismo Paulista e Republicanismo Gaúcho, entre o Partido de Classe e o Partido de Estado: Aproximações e Distinções (1873-1930)". Almanack, no 2, pp. 101-113.

PINTO, Surama Conde Sá. (2011), Só para Iniciados... O Jogo Político na Antiga Capital Federal. Rio de Janeiro, Mauad.

PORTO, Walter Costa. (2002), O Voto no Brasil. Rio de Janeiro, Topbooks. (2004), A Mentirosa Urna. São Paulo, Martins Fontes.

POSADA-CARBÓ, Eduardo. (2000), “Electoral Juggling: A Comparative History of the Corruption of Suffrage". Journal of Latin American Studies, vol. 32, no 3, pp. 611-644.

RESENDE, Maria Efigenia Lage de. (1982), Formação da Estrutura de Dominação em Minas Gerais: O Novo PRM (1889-1906). Belo Horizonte, UFMG Editora.

RICCI, Paolo e ZULINI, Jaqueline Porto. (2012), “'Beheading', Rule Manipulation and Fraud: The Approval of Election Results in Brazil, 1894-1930". Journal of Latin American Studies, vol. 44, no 3, pp. 495-521.

. (2013), "Quem Ganhou as Eleições? A Validação dos Resultados antes da Criação da Justiça Eleitoral". Revista de Sociologia Política, vol. 21, no 45, pp. 91-105. 
SAMPAIO, Consuelo Novais. (1975), Os Partidos Políticos na Bahia na Primeira República: Uma Política de Acomodação. Salvador, UFBA.

SANTOS, Wanderley Guilherme dos. (2013), “O Sistema Oligárquico Representativo da Primeira República". DADOS - Revista de Ciências Sociais, vol. 56, no 1, pp. 9-37.

TELAROLLI, Rodolpho. (1982), Eleições e Fraudes Eleitorais na República Velha. São Paulo, Brasiliense.

VENEU, Marcos Guedes. (1987), “Enferrujando o Sonho: Partidos e Eleições no Rio de Janeiro, 1889-1895". DADOS - Revista de Ciências Sociais, vol. 30, no 1, pp. 45-72.

VISCARDI, Claudia Maria Ribeiro. (2012), O Teatro das Oligarquias. Uma Revisão da Politica do Café com Leite. Belo Horizonte, Fino Traço.

WOODARD, James P. (2005), “History, Sociology and the Political Conflicts of the 1920s in São Paulo, Brazil”. Journal of Latin American Studies, vol. 37, no 2, pp. 333-349.

ZIBLATT, Daniel. (2009), "Shaping Democratic Practice and the Causes of Electoral Fraud: The Case of Nineteenth-Century Germany Harvard University". American Political Science Review, vol. 103, no 1, pp. 1-21. 


\section{APÊNDICE}

\section{Nota Metodológica}

Tanto os resultados eleitorais quanto as filiações partidárias dos candidatos à Câmara Federal foram coletados por meio de diferentes fontes. A princípio, os dados relativos aos resultados dos 11 pleitos considerados neste artigo foram colhidos diretamente dos relatórios das Comissões de Inquérito, encarregadas de se pronunciar sobre a lisura de todos os escrutínios, sem exceção, pela letra do regimento interno. Via de regra, os pareceres recuperavam a listagem elaborada pela secretaria-geral da Câmara, que avaliava cada escrutínio tomando por base as informações sumarizadas na ata geral de apuração lavrada pela Junta Apuradora Geral, órgão responsável pela condução do processo de contagem dos sufrágios e divulgação do resultado do pleito. Este saldo era sucessivamente despachado às respectivas Comissões de Inquérito, incumbidas de analisar, novamente, todos os pleitos eleitorais.

Infelizmente, a leitura dos relatórios destas comissões revela que, em pouquíssimos casos, se publicava a votação de todos os candidatos. Isso inviabilizava, de imediato, o recurso ao índice do número de candidatos efetivos na mensuração da competição eleitoral. A alternativa foi calcular a competição através da diferença entre os votos do último dos eleitos e os do primeiro dos não eleitos a partir da relação de nomes indicada pela secretaria da Câmara - então reproduzida nos relatórios das Comissões de Inquérito - ou pela lista apresentada pelas Juntas Apuradoras - também disponível nos pareceres das comissões. Esta estratégia permitiu identificar a diferença, por distrito, entre os votos do último candidato dado por eleito em relação aos votos do primeiro candidato não eleito para $330(67,9 \%)$ dos 495 distritos entre os anos 1900 e 1930. Nos demais casos, porém, não havia como obter o resultado eleitoral completo já que os balanços das Comissões de Inquérito reproduziam apenas os votos dos deputados a serem reconhecidos, desconsiderando as votações dos derrotados. A saída para estes casos foi investir na procura dessas informações em jornais de época ${ }^{*}$, que acompanhavam o desenrolar das apurações, atualizando o posicionamento dos candidatos até a totalização dos votos ser atingida. Isso nos permitiu aumentar para $83 \%$ do total o número de distritos eleitorais com da-

* Listamos as principais folhas consideradas: O Paiz, Correio Paulistano, Jornal do Brasil, A Pacotilha, Gazeta de Noticias, Estado da Paraiba, A União, Diario de Pernambuco, Diario da Bahia, A Federação, A Republica, Gazeta de Minas, Minas Geraes. 
dos ao nível de competição eleitoral. Os periódicos foram também consultados para reconstruir as chapas dos partidos em disputa. Foi dessa forma que conseguimos mapear o partido de pertencimento dos candidatos aos pleitos republicanos. 


\title{
RESUMO
}

Partidos, Competição Política e Fraude Eleitoral: A Tônica das Eleições na Primeira República

Este artigo revisita as práticas eleitorais no Brasil republicano (1891-1930). Partimos da crítica da farsa eleitoral, incômodo consensual na literatura dedicada à historiografia política da época. Através do exame acurado das contestações dirigidas à Câmara Baixa por alguns dos candidatos derrotados nos pleitos realizados para preenchimento das cadeiras desta Casa representativa, veremos que as alegações de fraude se faziam reflexo de um processo mais complexo, sobretudo fruto da competição desencadeada no âmbito subnacional, expressão de embate direto entre facções estaduais rivais. A análise desta rica fonte revela que o estímulo elementar da competição político-partidária nos anos 1900 era a concorrência pelo controle da máquina administrativa das eleições, financiadora inconteste do condicionamento dos resultados dos escrutínios.

Palavras-chave: Primeira República; sistema representativo; competição política; fraude eleitoral; eleições

\begin{abstract}
Parties, Political Competitions and Electoral Fraud: Elections during the Brazilian First Republic

This article turns to the electoral practices during the Brazilian First Republic (1891-1930). The starting point is a critique of the historiography's malaise with the consensual notion of rampant electoral fraud. Through an in-depth examination of the complaints submitted to the Lower House by defeated candidates, it is possibly to observe that fraud allegations were a reflex of a more complex process and mainly the product of the competition unleashed at the subnational level among rival state factions. The analysis of this rich source reveals that the main incentive to enter political competition in the 1900s was indeed control of the electoral administrative apparatus, undoubtedly the main force behind the conditioning of electoral results.
\end{abstract}

Keywords: Brazilian First Republic; representative system; political competition; electoral fraud; elections 


\section{RÉSUMÉ}

Partis, Compétition Politique et Fraude Électorale: Le Ton des Élections Pendant la Première République Brésilienne

Dans cet article, on examine les pratiques électorales au Brésil pendant la période 1891-1930. On part de la critique de la farce électorale, une gêne consensuelle présente dans la littérature d'historiographie politique de l'époque. En examinant attentivement les contestations adressées à la Chambre Basse par certains candidats défaits aux élections de cette Chambre, on se rend compte que les allégations de fraude n'étaient que le reflet d'un processus plus complexe, résultant de la compétition déclenchée au niveau régional, reflet des heurts directs entre factions rivales des états brésiliens. L'analyse de cette source importante montre que ce qui stimulait essentiellement la compétition entre les partis dans les années 1900 était le contrôle de l'appareil administratif des élections, incontestable garant des résultats des scrutins.

Mots-clés: Première République Brésilienne; système représentatif; compétition politique; fraude électorale; élections

\section{RESUMEN}

Partidos, Competencia Política y Fraude Electoral: La Tónica de las Elecciones en la Primera República Brasileña

Este artículo examina las prácticas electorales del Brasil republicano (1891-1930). Partimos de la crítica a la farsa electoral, incomodidad consensuada en la literatura dedicada a la historiografía política de la época. A través del cuidadoso examen de los escritos de oposición que algunos de los candidatos derrotados en las elecciones dirigieron a la Cámara Baja, veremos que las acusaciones de fraude eran el reflejo de un proceso más complejo, fruto, sobretodo, de la competición que se desencadenó en el ámbito subnacional, expresión del enfrentamiento directo entre facciones estaduales rivales. El análisis de esta rica fuente revela que el estímulo elemental de la competencia político-partidaria en los años 1900 era la disputa por el control de la máquina administrativa de las elecciones que, indiscutiblemente, financiaba el condicionamiento de los resultados de los escrutinios.

Palabras clave: Primera República Brasileña; sistema representativo; competencia política; fraude electoral; elecciones 